UDC: $\mathbf{3 1 1 . 1 7}$

JEL Classification: C15

doi: $10.31767 /$ nasoa.3-2020.01

N. HRYNCHAK,

Senior Lecturer of Department for Economics and Management of Foreign Economic Activities, National Academy of Statistics, Accounting and Audit, e-mail: gnatalia@ukr.net,

ORCID: 0000-0002-2046-6014,

Researcher ID: I-9495-2018

\title{
Studies of the Logistics Services Market: Information and Analytical Support and a System of Statistical Indicators
}

Information and analytical database for the market support is required to prevent communications of contradictory information to higher levels of management, with adverse effects for the process of taking rational management decisions. The article's objective is to substantiate the information and analytical support for studies of the logistics services market, with constructing a system of statistical indicators for this market assessment, to be laid as the solid basis for elaborating medium-term and long-term strategies and policies of the logistics services market in Ukraine.

A definition of information and analytical support for studies of the logistics services market is given; a review of secondary sources of data for this market studies is made. A conceptual model for information and analytical studies of the logistics services market is proposed. The key statistical indicators for studies of this market are identified, with substantiating the feasibility of their use in computing multivariate indicators for the assessment of performance and capacities of the logistics services market in Ukraine. The core criteria to be met by the abovementioned system of statistical indicators are highlighted. A system of statistical indicators for the assessment of the logistics services market is proposed, containing four modules. It allows for diagnosis of this market performance and tendencies, with accounting for the impact of other related markets and activities, and for forecasting. This system, constructed with consideration to the global practice, is designed for comprehensive studies of the logistics services market.

Keywords: data sources, information and analytical support, logistics services market, statistical indicator.

Н. А. ГРИНЧАК,

стариий викладач

кафедри економіки та менеджменту зовнішньоекономічної діяльності,

Національна академія статистики, обліку та аудиту

\section{Інформаційно-аналітичне забезпечення та система статистичних показників дослідження ринку логістичних послуг}

В статті обтрунтовано інформачійно-аналітичне забезпечення дослідження ринку логістичних послуг та сформовано систему статистичних показників дослідження иього ринку. На основі розробленої автором концептуальної моделі інформаційно-аналітичного дослідження ринку логістичних послуг запропоновано систему статистичних показників для оцінювання ринку логістичних послуг, яка містить 4 блоки та дозволяє діагностувати стан і тендениії розвитку зазначеного ринку, враховуючи вплив інших суміжних ринків та видів економічної діяльності, а також здійснювати прогноз розвитку ринку логістичних послуг в Україні.

Ключові слова: джерела даних, інформачійно-аналітичне забезпечення, ринок логістичних послуг, статистичний показник.

(C) N. Hrynchak, 2020 
Introduction. When there is no information and analytical database for the market support, build on integrated principles, contradictory information may be communicated to higher levels of management, with adverse effects for the process of taking rational management decisions. Also, problems of statistical studies of the logistics services market can be caused by the existence of considerable numbers of methods for identification of the logistics services market, which, however, are impracticable, incomplete or inconsistent; this leads to heterogeneous or inaccurate results not allowing to investigate the logistics services market in an appropriate manner.

The abovementioned raises the importance of creating the information and analytical support for the logistics services market, to be laid as the basis for constructing an effective system of statistical indicators for studies of the logistics services market. This system of indicators is designed for identifying territorial and sectoral disproportions and reserves, with constructing tools helping achieve the sustainable and effective performance of the logistics system, harmonized with the pace of the economy's evolution.

Literature review. Theoretical and practical aspects of the logistics services market have been subject of research by domestic scientists such as M. Yu. Hryhorak [1], Ye. V. Krykavskyi [2], S. S. Lysa [3] O. Ye. Shandrivska [2, 4], L. Ya. Yakymyshyn [4] and others. Methodological issues of the assessment of domestic logistics services market were dealt with foreign researchers: T. Elger, K.-J. Lundquist, L.-O. Olander [5]; K. Rantasila and L. Ojala [6]; B. Shepherd [7]; M. Steglich, D. Feige, P. Klaus [8], C. Yu [9]. Also, the methodological framework for constructing a system of statistical indicators for analyses of the logistics services market and its information support has been in focus of international institutions such as International Transport Forum, World Bank, European Commission and others.

In spite of a strong emphasis on the abovementioned aspects, issues related with the conceptual model for the information and analytical support to studies of the logistics services market in Ukraine and constructing a system of respective statistical indicators require further studies.

The article's objective is to substantiate the information and analytical support for studies of the logistics services market, with constructing a system of statistical indicators for research purposes, to be laid as the solid basis for elaborating medium-term and long-term strategies and policies of the logistics services market in Ukraine.

Results. Information support for studies of the logistics services market should be defined as "a set of information contained in databases, and information technologies and technical means designed for its processing". Information support can enhance the effectiveness of analytical processes that are the key to analyses of any kind of market. The effectiveness of analytical processes can be achieved through reducing time and labor costs for the search of necessary information and carrying out analyses.

Researchers have not elaborated a single conceptual approach to understanding the essence of the logistics services market, its determining factors and a method for its assessment. In spite that the scopes of statistical data and other sources for studies of the logistics services market increased over the past few years, a consistent conceptual model for the information and analytical support for statistical studies of the logistics services market is yet to be built. Although statistical and analytical reports are a secondary source of information for assessing national and global logistics services markets, they are essentially important in constructing an adequate statistical base for medium-term and long-term strategy and policy for the development of the logistics services market in Ukraine (Table).

Table

\section{A review of selected secondary sources of data required for studies} of the logistics services market

\begin{tabular}{|c|l|c|c|c|}
\hline \multicolumn{1}{|c|}{ Organization / Title of edition } & $\begin{array}{l}\text { Type / method } \\
\text { of the study }\end{array}$ & $\begin{array}{c}\text { Approach } \\
\text { to the study }\end{array}$ & $\begin{array}{c}\text { Periodicity } \\
\text { of } \\
\text { publication }\end{array}$ & \multicolumn{1}{|c|}{$\begin{array}{c}\text { Geographic } \\
\text { coverage }\end{array}$} \\
\hline 1 & 2 & 3 & 4 & 5 \\
\hline $\begin{array}{l}\text { Economy Watch / Economic Statistics } \\
\text { Database [10] }\end{array}$ & $\begin{array}{l}\text { Secondary } \\
\text { data }\end{array}$ & $\begin{array}{l}\text { Quantitative } \\
\text { assessment }\end{array}$ & Annual & $\begin{array}{l}\text { National, } \\
\text { global, } \\
\text { regional }\end{array}$ \\
\hline
\end{tabular}




\begin{tabular}{|c|c|c|c|c|}
\hline & & & & Table \\
\hline 1 & 2 & 3 & 4 & 5 \\
\hline $\begin{array}{l}\text { Fraunhofer SCS / The standard } \\
\text { reference work for the logistics } \\
\text { industry "TOP } 100 \text { in European } \\
\text { Transport and Logistics Services" [11] }\end{array}$ & $\begin{array}{l}\text { Secondary } \\
\text { data; } \\
\text { interviews and } \\
\text { questionings }\end{array}$ & $\begin{array}{l}\text { Quantitative } \\
\text { and qualitative } \\
\text { assessment }\end{array}$ & Biannual & $\begin{array}{l}\text { EU, national } \\
\text { markets of EU } \\
\text { countries }\end{array}$ \\
\hline $\begin{array}{l}\text { International Transport Forum / Key } \\
\text { Transport Statistics }[12,13]\end{array}$ & $\begin{array}{l}\text { Questionings } \\
\text { and case } \\
\text { studies }\end{array}$ & $\begin{array}{l}\text { Quantitative } \\
\text { assessment }\end{array}$ & Annual & $\begin{array}{l}\text { Global and } \\
\text { national } \\
\text { markets }\end{array}$ \\
\hline $\begin{array}{l}\text { Organization for Economic } \\
\text { Cooperation and Development / } \\
\text { Economic Outlook. OECD.Stat [14] }\end{array}$ & Анкетування & $\begin{array}{l}\text { Quantitative } \\
\text { assessment }\end{array}$ & Annual & $\begin{array}{l}\text { Global and } \\
\text { national } \\
\text { markets }\end{array}$ \\
\hline $\begin{array}{l}\text { World Bank / Connecting to Compete: } \\
\text { Trade Logistics in the Global } \\
\text { Economy / Logistics Performance } \\
\text { Indicator }[15,16]\end{array}$ & Questionings & $\begin{array}{l}\text { Analytical } \\
\text { assessment }\end{array}$ & Annual & $\begin{array}{l}\text { Global and } \\
\text { national } \\
\text { markets }\end{array}$ \\
\hline $\begin{array}{l}\text { Transport Intelligence / } \\
\text { Emerging Market Logistics Index [17] }\end{array}$ & Questionings & $\begin{array}{l}\text { Analytical } \\
\text { assessment }\end{array}$ & Annual & $\begin{array}{l}\text { Regional } \\
\text { and national } \\
\text { markets }\end{array}$ \\
\hline $\begin{array}{l}\text { United Nations Conference on } \\
\text { Trade and Development / Review of } \\
\text { Maritime Transport [18] }\end{array}$ & $\begin{array}{l}\text { Secondary } \\
\text { data }\end{array}$ & $\begin{array}{l}\text { Quantitative } \\
\text { assessment }\end{array}$ & Annual & $\begin{array}{l}\text { Global and } \\
\text { national } \\
\text { markets }\end{array}$ \\
\hline $\begin{array}{l}\text { State Statistics Service of Ukraine / } \\
\text { Business performance. Transport and } \\
\text { communication of Ukraine [19] }\end{array}$ & $\begin{array}{l}\text { Secondary } \\
\text { data }\end{array}$ & $\begin{array}{l}\text { Quantitative } \\
\text { assessment }\end{array}$ & Annual & $\begin{array}{l}\text { National } \\
\text { market }\end{array}$ \\
\hline
\end{tabular}

Source: compiled by the author

Considering that the information and analytical support for studying the logistics services market has to meet all the information needs of management and rationalize the process of taking management decisions, we are going to propose the below given model for information and analytical support for studies of the logistics services market (Figure 1).

Not all the studies that are of relevance today can be conducted by use of the available statistical data. A statistical study of the logistics services market requires a scientifically sound system of statistical indicators. It can be used to determine the scopes (levels), structure, dynamics and relationships between results and factors with impact on the statistics services market. Therefore, statistics provides for the quantification of tendencies and relationships specific to the development of the logistics services market. A system of statistical indicators needs to be constructed by reliance on the socio-economic theory framework and the principle of dialectic method of cognition.

Constructing a scientifically sound system of statistical indicators and investigating the performance of the logistics services market, with characterization of all the components of the market structure is extremely important and necessary objective considering the development of international transport corridors, the economic attractiveness of multimodal transportations and search for the optimal operation of regional transport systems. Besides that, further developments the strategy for the logistics services market and its capacity building need to rely on the comprehensive assessment that accounts for the specifics of geographic location of productive forces [20].

A system of statistical indicators for studies of the logistics services market needs to comply with the following set of core criteria:

- the statistical indicators must be correct, quantifiable, and must have a reliability required for practical purposes;

- the statistical indicators must be aggregated: it means that when aggregated they must allow for moving from one level to another by use of various statistical methods;

- the statistical indicators must be politically neutral and applicable for an economicstatistical analysis with identification of the causalities. 


\section{Information and analytical support for studies of the logistics services market}

\begin{tabular}{|c|c|}
\hline \multicolumn{2}{|c|}{ Principles of statistical support for studies of the logistics services market } \\
\hline $\begin{array}{l}\quad \text { General principles } \\
\text { - consistency; } \\
\text { - effectiveness; } \\
\text { - scientific validity; } \\
\text { - purposefulness; } \\
\text { - formalization }\end{array}$ & $\begin{array}{l}\stackrel{\text { Applied principles }}{\longrightarrow} \\
\text { - dynamism; } \\
\text { - cyclicality; } \\
\text { - flexibility; } \\
\text { - specificity of development }\end{array}$ \\
\hline \multicolumn{2}{|c|}{ Information base for statistical support for studies of the logistics services market } \\
\hline $\begin{array}{l}\text { - statistical observations of } \\
\text { - customs statistics of the } \mathrm{St} \\
\text { - statistical and financial rep } \\
\text { - statistical observations of } \\
\text { organizations; } \\
\text { - Internet database of the } \mathrm{Ur}\end{array}$ & $\begin{array}{l}\text { vice of Ukraine and its units; } \\
\text { Jkraine; } \\
\text { tsia" (Ukrainian railway) Company; } \\
\text { UNCTAD and other information } \\
\text { Trademark Office (USPTO) }\end{array}$ \\
\hline
\end{tabular}

\begin{tabular}{|c|c|c|}
\hline \multicolumn{3}{|c|}{ Analytical tools for statistical support for studies of the logistic s services market } \\
\hline & $\downarrow$ & \\
\hline $\begin{array}{l}\text { Economic diagnostics } \\
\text { - create a system of } \\
\text { indicators measuring the } \\
\text { current performance of the } \\
\text { logistics services market; } \\
\text { - compare the indicators } \\
\text { with the benchmark } \\
\text { values; } \\
\text { - define the vector of } \\
\text { change }\end{array}$ & $\begin{array}{l}\text { Research methods } \\
\text { - method of summary } \\
\text { indicators; } \\
\text { - multivariate mean; } \\
\text { - analysis of dynamic } \\
\text { series; } \\
\text { - patent analysis etc. }\end{array}$ & $\begin{array}{l}\text { Modeling methods } \\
\text { - trend, adaptive and } \\
\text { autoregression models for } \\
\text { forecasting main indicators } \\
\text { of the logistics services } \\
\text { market; } \\
\text { - correlation-regression } \\
\text { analysis; } \\
\text { - cluster analysis }\end{array}$ \\
\hline
\end{tabular}

\section{Figure 1. A conceptual model for information and analytical studies of the logistics services market}

Source: constructed by the author

A system of statistical indicators for the assessment of the logistics services market is proposed, consisting of four modules. It allows for diagnosis of this market performance and tendencies, with accounting for the impact of other related markets and activities, and for forecasting and modeling of the developments at the Ukrainian logistics services market. This system, constructed with consideration to the global practice, is designed for comprehensive studies of the logistics services market (Figure 2).

As there is no aggregated indicator that would allow for measuring the size of the logistics services market in Ukraine, a system of indicators is proposed for a comprehensive study of this market. The periodicity with which the indicators are to be computed should be determined with account for the internal environment of Ukraine. The main source of data is monthly, quarterly and annual reporting. For some of the indicators demonstrating slow dynamics, data can well be reported once in several years.

Statistical observations of the State Statistics Service of Ukraine are the most useful source of comparable, complex, consistent, reliable and scientifically valid data for the assessment of the logistics services market. 


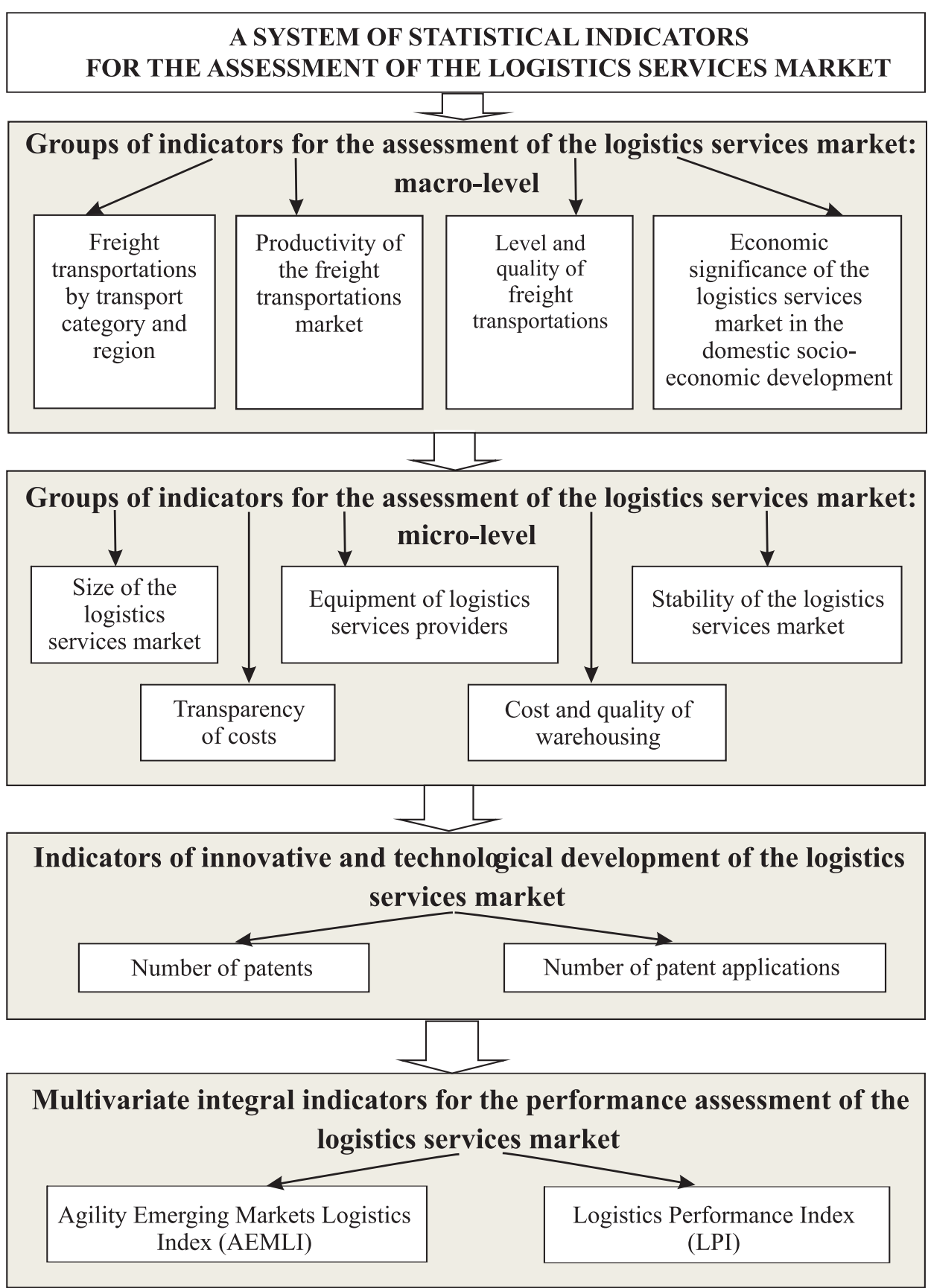

Figure 2. A system of statistical indicators for the assessment of the logistics services market

Source: constructed by the author

The system of indicators used for the analysis should be regularly revised and updated in order to maintain the relevance of the statistical database in view of the fluctuations in the logistics services market in Ukraine. Also, new data sources allowing for constructing new indicators should be subject to constant monitoring.

Conclusions. The study allowed for constructing a conceptual model for the information and analytical support to studies of the logistics services market, which covers a broad range of statistical information sources (e. g. statistical and financial reporting of companies, data 
of the State Statistics Service of Ukraine, the State Fiscal Service of Ukraine, international organizations), characterizing all the components of the logistics services market (transportation, warehousing, logistics infrastructure etc.) and methods of statistical study, allowing for management decisions on the development of the logistics services market in Ukraine, its transformation and integration in the global logistics system. A system of statistical indicators for the assessment of the logistics services market is proposed, consisting of four modules. It allows for diagnosis of this market performance and tendencies, with accounting for the impact of other related markets and activities, and for making forecasts for future. This system, constructed with consideration to the global practice, is designed for comprehensive studies of the logistics services market

\section{References}

1. Hryhorak M. Yu. (2017). Intelektualizatsiia rynku lohistychnykh posluh: kontseptsiia, metodolohiia, kompetentnist [Intelectualization of the logistics services market: concept, methodology, competence]. Kyiv: Sik Hrup Ukraina [in Ukrainian].

2. Krykavskyi Ye. V., Shandrivska O. Ye., Patora-Vysotska Z. (2017). Stratehichna otsinka perspektyv richkovykh vantazhnykh perevezen v Ukraini [A strategic assessment of the prospects of river freight transportations in Ukraine]. Visnyk Khmelnytskoho natsionalnoho universytetu. Ekonomichni nauky - Bulletin of Khmelnytsk National University. Economics, 6(1), 121-128. Retrieved from http://nbuv.gov.ua/UJRN/ Vchnu ekon 2017 6(1) 24 [in Ukrainian].

3. Lysa S. S. (2017). Rynok lohistychnykh posluh v Ukraini: dynamika, struktura perspektyvy [Logistics services in Ukraine: dynamics, structure, prospects.]. Tovary $i$ rynky - Commodities and markets, 2(2), 52-61. Retrieved from http://tr.knteu.kiev.ua/ files/2017/24(tom2)/6.pdf [in Ukrainian].

4. Shandrivska O. Ye., Yakymyshyn L. Ya. (2018). Doslidzhennia hlobalnoho rynku lohistychnykh posluh: svitovi tendentsii ta vplyv na Ukrainu [A study of the global logistics services market: global tendencies and effects for Ukraine]. Visnyk Natsionalnoho universytetu "Lvivska politekhnika”. Lohistyka - Bulletin of Lviv Politechnic National University. Logistics, 892, 212-221. Retrieved from http://nbuv.gov.ua/UJRN/ VNULPL_2018_892_30 [in Ukrainian].

5. Elger T., Lundquist $\overline{\mathrm{K}}$.-J., Olander L.-O. (2008). Svensk Makrologistik, VINNOVA Rapporter 2008:13. Retrieved from http://www.vinnova.se/upload/EPiStorePDF/vr-0813.pdf

6. Rantasila K., Ojala L. M. (2015). National-level logistics costs : an overview of extant research . International journal of logistics: research and applications, 18(4), 313-324.

7. Shepherd B. (2011). Logistics Costs and Competitiveness: Measurement and Trade Policy Applications, Transport Support Research series, a joint World Bank/DFID initiative. Retrieved from http://siteresources.worldbank.org/INTTRANSPORT/Resou rces/336291-1239112757744/5997693-1294344242332/Logistics_costs.pdf

8. Steglich M., Feige D., Klaus P. (2016). Logistik-Entscheidungen: Modellbasierte Entscheidungsunterstützung in der Logistik mit Logistics Lab. De Gruyter, s. 471.

9. Yu C. (2015). The Analysis of the China National logistics costs structure. Management and engineering, 21, 77-84.

10. The official website Economy Watch. Retrieved from https://www.economywatch.com/ economic-statistics/

11. TOP 100 in European Transport and Logistics Services. Retrieved from https://www.scs. fraunhofer.de/en/publications/top100.html

12. The official website of the International Transport Forum. Retrieved from https://www. itf-oecd.org/

13. Key Transport Statistics 2019 Data. Retrieved from https://www.itf-oecd.org/sites/default/ files/docs/key-transport-statistics-2020.pdf

14. The official website of OECD. Statistics. Retrieved from https://stats.oecd.org/

15. Arvis J.-F., Ojala L., Wiederer C., Shepherd B., Raj A., Dairabayeva K., Kiiski T. Connecting to Compete 2018: The Logistics Performance Index and Its Indicators. Retrieved from https://www.researchgate.net/publication/327044979_Connecting_to_ Compete_2018_Trade_Logistics_in_the_Global_Economy 
16. The official website of World Bank. Retrieved from https://www.worldbank.org

17. Agility Emerging Markets Logistics Index 2020. Retrieved from https://www.agility.com/ insights/wp-content/uploads/2020/02/Agility-Emerging-Markets-Logistics-Index-2020. pdf

18. The official website UNCTAD. Statistics. Retrieved from https://unctadstat.unctad.org/

19. Ofitsiinyi sait Derzhavnoi sluzhby statystyky Ukrainy [The official website of the State Statistics Service of Ukraine]. Retrieved from http://www.ukrstat.gov.ua/ [in Ukrainian]

20. Kuhan S. F. Logisticheskiy potentsyal regiona kak obiyekt issledovaniya [The logistics capacities of a region as an object for study]. Retrieved from https://rep.bntu.by/bitstream/handle/data/52979/logisticheskij_potencial regiona kak obekt issledovaniya. pdf?sequence $=1$ [in Russian].

\section{Bibliographic description for quoting:}

Hrynchak N. (2020). Studies of the Logistics Services Market: Information and Analytical Support and a System of Statistical Indicators. Scientific Bulletin of National Academy of Statistics, Accounting and Audit - Naukovyy visnyk Natsionalnoi akademiyi statystyky, obliku ta audytu, 3, 5-11. doi: 10.31767/nasoa.3-2020.01. 